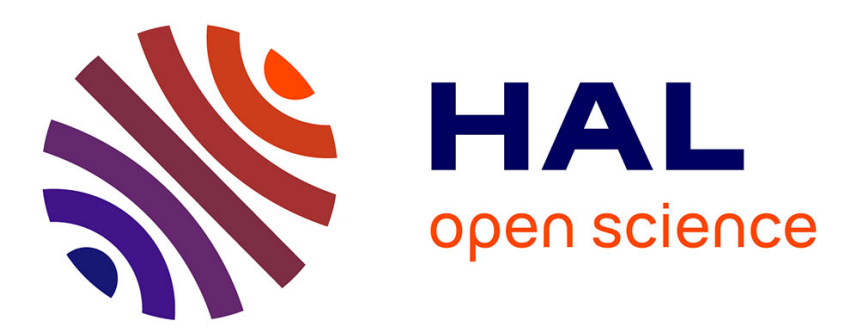

\title{
On the perceived justice of urban road pricing: An empirical study in Lyon
}

Stéphanie Souche, Charles Raux, Yves Croissant

\section{To cite this version:}

Stéphanie Souche, Charles Raux, Yves Croissant. On the perceived justice of urban road pricing: An empirical study in Lyon. Transportation Research Part A: Policy and Practice, 2012, 46 (7), pp.1124-1136. 10.1016/j.tra.2012.01.009 . halshs-01026420

\section{HAL Id: halshs-01026420 \\ https://shs.hal.science/halshs-01026420}

Submitted on 5 Nov 2014

HAL is a multi-disciplinary open access archive for the deposit and dissemination of scientific research documents, whether they are published or not. The documents may come from teaching and research institutions in France or abroad, or from public or private research centers.
L'archive ouverte pluridisciplinaire HAL, est destinée au dépôt et à la diffusion de documents scientifiques de niveau recherche, publiés ou non, émanant des établissements d'enseignement et de recherche français ou étrangers, des laboratoires publics ou privés. 


\title{
On the perceived justice of urban road pricing: an empirical study in Lyon
}

Author names: Stephanie Souche*, Charles Raux*, Yves Croissant**

Affiliations:

*Laboratoire d'Economie des Transports, University of Lyon and CNRS

**Université de La Réunion

Corresponding author:

e-mail: stephanie.souche@let.ish-lyon.cnrs.fr

Postal address:

Stephanie Souche

ISH, 14 av. Berthelot

69363 Lyon, France

Tel: $+33(0) 4 / 72 / 72 / 64 / 57$

Fax: $+33(0) 4 / 72 / 72 / 64 / 48$

\begin{abstract}
Various methods of restricting automobile traffic, by price (tolls) or by quantity (odd/even license plates or limited days of traffic), are tested in a survey $(\mathrm{N} \sim 400)$ about attitudes toward traffic restrictions in Lyon, France. Ordered probit models with a random-effects panel allow us to estimate the survey respondents' perceptions of these methods, as well as the roles of individual socio-demographic characteristics in the formation of these perceptions. Both the restriction of automobile traffic and its regulation by congestion (waiting in line) are widely considered unjust by the respondents, regardless of whether they work and whether they are drivers or non-drivers. Their attitudes towards tolls justified by the pollution caused by automobile traffic are less negative. As regards compensation, in addition to emergency vehicles and those that transport people with limited mobility, respondents believe carpooling ought to benefit of a toll exemption. The support for a reduced rate for low-income users shows a concern for justice to which it will be necessary to respond. The respondents' socio-professional status, level of education, car use or non-use, and residence inside or outside of the toll zone clearly play a role in their perceptions of these methods of regulation and compensation.
\end{abstract}

Key-words: urban road pricing, justice, attitudes, ordered probit with random-effects panel

Classification J.E.L.: R41, R48, C35 


\section{Introduction}

London, Stockholm or Milan are signature examples of the recent implementation of urban road user charging (for London, see Santos and Fraser, 2006 and Leape, 2005; for Stockholm, see Eliasson, 2008; for Milan, see Rotaris et al., 2010). These implementations represent the concrete realisation of relatively old economic ideas, such as the use of price (or taxes) to regulate the consumption of, or access to, scarce resources (Pigou, 1920), through the use of road tolls to effectively regulate congestion (Walters, 1961; Vickrey, 1963).

Following these examples, other cities around the world plan to implement similar regulatory schemes. However, at the same time, many advanced urban toll projects have been rejected by the resident populations through ex-ante referenda, such as those in Edinburgh and Manchester (Riley and Gjersoe, 2006), or other political processes, as in Manhattan (Schaller, 2010).

The evaluation of the costs and benefits that result from changes (Prud'Homme and Kopp, 2005; Mackie, 2005; Santos and Bhakar, 2006; Jansson, 2008; Eliasson, 2009) is necessary to understand this question of acceptability. However, acceptability is a more complex notion which remains subject to debate (Marccucci, 2001 and for a survey see Schade and Schlag, 2003). A part of this debate is focused on the question of justice. Authors are interested in analysing the distribution effects of road pricing (see Richardson, 1974; Small, 1983; Cohen, 1987; Giuliano, 1992; Gomez-Ibanez and Meyer, 1993; Bureau and Glachant, 2008). They evaluate and compare the progressivity of different road pricing schemes and identify "winners " and "losers" groups. Without compensation mechanisms, Small (1983) or Giuliano (1992) show that low income category loses most with a road pricing measure. More recently, Ramjerdi (2006) and Karlström and Franklin (2009) use Gini and Theil indicators to point out an increase of income dispersion after road pricing implementation.

The perceived justice of a situation is also important to understand people attitudes. Konow (2003) proposes a positive theory of justice based on principles of justice. The literature on principles of justice is vast and clearly exceeds the strict question of transportation (Kahneman et al., 1986; Zajac, 1995; Young, 1995; Raux et al., 2009). However after a broad literature review, Konow concludes that perceptions of justice depend on the context, which includes the nature of the good to be shared and the individuals' personal characteristics, values and beliefs, but also what is normal, customary and expected in the type of situation in question.

Following Konow, we want to understand this perception of justice in the road pricing case study. Thus, the persistent resistance to regulation by prices leads us to examine why the implementation of an urban toll was perceived as unjust and whether direct compensation, in specified forms, would receive the support of the population. To our knowledge, only Baron and Jurney (2003) and Eriksson et al. (2006) works tackle this issue using this justice perception but without reference to justice principles.

The basis of our study is an opinion survey of around 400 people in the Lyon metropolitan area of France to whom we present a potential toll situation in the city centre. We conduct an in-depth econometric analysis of different methods of regulation by quantities or by queuing to see if they receive more support than pure price regulation. Different forms of compensation are also considered. 
Our results show that restriction based on price or quantity is generally considered unjust. At the same time, urban tolls are considered less unjust if they hold automobile drivers responsible for reducing pollution. Moreover, there are significant differences depending on the employment statuses of the respondents (working/non working), their socio-professional statuses, their educational levels and their use or non-use of automobiles. We also demonstrate the existence of a "moral" or "ethical" dimension of the compensation, which is clearly distinguished from other aspects of compensation and plays the role of a true "reference transaction" (Kahneman et al., 1986). Finally, our results shed light on the factors involved in the acceptance of tolls.

It seems indispensable for us to proceed first with a literature review, which enables us to formulate the questions that we then test empirically with a survey. Second, in the methodological section, we present the survey, the questionnaire and the ordered probit model with random-effects panel. Finally, we present and discuss the results of this analysis.

\section{Literature review and questions}

Perceptions of the justice of various methods of allocating scarce resources were tested empirically by Frey and Pommerehne (1993), using water as an example. These authors show that the rules of allocation by price are considered less fair than a bureaucratic procedure (in which the administration performs the allocation on the basis of its own judgement) but more fair than allocation by lottery. The queuing method is considered the fairest.

Conversely, Taylor et al. (2003) show that in the absence of a price system, a lottery is generally more acceptable than the queuing method. In accordance with the economic theory of bureaucracy (Niskanen, 1971), the bureaucratic procedure is considered especially intrinsically unjust.

By exploring situations of scarce parking spaces or seats on a train, Raux et al. (2009) show that regulation by price is still overwhelmingly rejected. They find that the order of preference of regulation methods, from the most to the least fair, is as follows: queuing and peak pricing with an additional service (seats on a train or additional parking spaces), peak pricing with a constant level of service, administrative allocation, and assignment by lottery. However, this study confirms the influence of context, notably depending on the type of good being studied, on the perception of these allocation methods.

Therefore, it seems essential to test these regulation methods in the specific case of transportation and urban tolls (Question 1).

Question 1: To solve a problem of excessive demand in urban transportation, is regulation by queuing or a quantity control considered fairer than regulation by price control?

For Kahneman et al. (1986), injustice occurs when the exchange no longer considers the "reference transaction," such as when the exchange consists of rules that are largely used in commercial or administrative organisations, like waiting in line ("first come, first served"), or when priority is given in these lines to pregnant women or to handicapped people. The exchange can also consist of "reference prices", that is to say current prices observed in the market.

Meanwhile, Vaidyanathan and Aggarwal (2003) and Bolton et al. (2003) show that an offer of an additional service that justifies the price increase can change the negative attitudes that formed response to the reference transaction. Raux et al. (2009) likewise show that 
accompanying the price increase with an additional service can reduce opposition in cases involving certain goods, such as parking spaces or seats on a train.

So it seemed interesting to see whether the proposal of additional supply which justifies the price increase can modify attitudes to allocation by prices (Question 2).

Question 2: Can the addition of an extra service tied to the price increase cause the price increase to be perceived as more just in the case of urban tolls?

The question of compensation is at the forefront of this issue. It has been established since the works of Hicks (1939) and Kaldor (1939) that, in the context of standard cost-benefit analysis, compensation can justify a policy as long as the benefits accorded to the winners are greater than the losses of the losers. Thus, in theory, effective compensation could counterbalance the perceived injustice of a price-based regulation mechanism.

Frey and Oberholzer-Gee (1996), however, are critical of the use of compensation. In a situation where the debate relates to the installation of equipment not desired by neighbours, such as nuclear waste, Frey and Oberholzer identify four principal reasons for opposition to compensation. First, the direct and visible transfer of money can be perceived by the neighbours as a bribe. In this case, the compensation reinforces the local opposition. Second, the explicit monetary compensation can also be considered an implicit admission of the risk imposed by the installation and could lead to demands by the neighbours for an unreasonable level of compensation. Third, the neighbours may equate acceptance of monetary compensation with accepting a certain status quo. In other words, it may give the impression that the parties have reached an agreement even when the neighbours consider the measure unjust. Finally, if citizens would otherwise have accepted an unwanted installation out of social obligation, the offer of monetary compensation undermines the neighbours' sense of civic duty and reduces the possibility of such acquiescence. Frey et al. (1996) show that the compensation mechanism is incomplete because it ignores the influence of moral principles. When public spirit prevails, monetary compensation for nuclear waste installations is less acceptable because the monetary reward deprives individuals of the opportunity to yield to altruistic sentiments.

From the works of Zajac (1995), one can identify different principles of positive justice. For example, economic rights dictate that no one can receive less than a minimal sum to satisfy his basic economic needs (Konow, 2003). Under these circumstances, the denial of basic economic rights is considered unjust. In addition, when circumstances permit, equal distribution according to the principle of equality of rights and pains provides an element of justice.

Based on the principles stated by Rawls in his theory of justice (1971), Raux and Souche (2004) developed a framework to analyse the acceptability of price changes in the transportation sector that combines economic efficiency with three dimensions of equity: vertical equity, which directs attention to the most economically vulnerable people; horizontal equity, which divides cost among payers and users of transportation and among users of different modes of transportation; and territorial equity, which refers to guaranteed access to amenities and the freedom to come and go.

So the third question relates to the compensation proposed (Question 3).

Question 3: Are the different forms of compensation proposed-compensation as a function of revenues, of location, of professional activity, or of mobility practices-considered fair?

In studying the principles of regulation and compensation, it is important to establish whether people's economic situations affect their attitudes toward justice. According to Sah (1987), the 
poor would gain more through the use of rationing, and the rich benefit more from regulation by the market. In Stockholm, Armelius and Hultkrantz (2006) show that the middle income classes who use the car and who live on the outskirts of Stockholm lose the most when a toll is introduced. For Eliasson and Mattson (2006), the impact of a toll on this population category would increase as their incomes and capacities to adapt decrease. Their capacities to adapt depend on their travel purposes. The work purpose allows them the least latitude.

Furthermore, agents can be strategic in their response. Hurd et al. (1998) point out the strategic misrepresentation of the respondent when he anticipates a possible link between his response and some economic outcome in which he has an interest. In our survey, agents will be strategic because we present them with a road pricing scheme they will have to pay and which is quite close to their situation. We don't want to deny this bias: we want to get more information about this strategic behaviour in particular in relation with the respondent own situation.

This review of the literature on urban road pricing shows that working people are the most penalised by the introduction of urban tolls. This penalisation occurs whether the workers live inside or outside the toll zone and regardless of whether they are in management positions. In other words, it seems that whether an individual works is the most discriminating variable in determining her perception of the toll. We hypothesise that this result will also be valid in the case of Lyon. This drives us to Question 4.

Question 4: Do the attitudes of the respondents vary as functions of their personal socioeconomic situations?

The questions that we have just presented were the subject of the empirical investigation based on a survey that we shall now describe.

\section{Methodology, survey and econometric model}

\subsection{The survey and the questionnaire}

The survey comprised face-to-face interviews of 401 people, a representative sample of the inhabitants of the Lyon metropolitan area (whose total population is 1.2 million) in January 2003. Respondents were randomly chosen according to the quota method (place of residence, age classes, gender and employment status) representative of the city of Lyon.

Acknowledging that increased automobile traffic in large cities poses more and more serious problems, including congestion, pollution, noise and lack of safety, researchers suggested introducing a toll for driving in the city. That is to say drivers who travel inside the toll zone have to pay. It is important to note that such a transportation policy measure was not being debated publicly in Lyon or in France at the time (see the questionnaire in Annex 1). Furthermore, Lyon is not a particular city in terms of transport pricing in France. Drivers have to pay excise taxes on oil (nationally fixed), on car purchase (depending on vehicle axle), for getting a driving license (the same for everyone) and to park their car in some dense areas (with a discount rate for handicapped). Then because of the congestion, the principle "first come, first served" is the reference for private cars.

The literature review has enabled us to identify relevant question. We want to test these in a real situation. We detail and adapt these questions to a familiar situation for people and then test them empirically with the survey. London and others urban congestion pricing experiences give us a useful help to translate relevant question into more familiar ones (see 
Santos, 2004). Although fictional, the story described situations, which were grounded in reality. Different methods for solving problems of congestion or of pollution (i.e., of excessive demand) were proposed, as well as different forms of compensation in case of road pricing; for each of the solutions, respondents were asked whether they found it very fair, rather fair, rather unfair or very unfair (see Annex 1).

The following regulation methods were presented to the respondents:

- Queuing (or "first come, first served" procedure) is the traditional management method. It entails allowing automobile transport to regulate itself based on the level of traffic ("Queuing") (see Question 1 in the previous literature review).

- Two methods of regulating by allocating quantities fixed by the administration were proposed: administrative rule 1, limiting cars to driving three days of the driver's choice per week between Monday and Friday (" 3 days"), and administrative rule 2, allowing cars to drive only every other day, with days assigned according to their license plates (“Odd/Even") (see Question 1).

- "Peak pricing with a constant level of service" is the classic method recommended by economists that reflects the scarcity of resources. This method involves charging a toll, either in peak periods ("Peak pricing"), or to hold drivers accountable for the pollution resulting from the automobile traffic ("Pollution") (Question 1).

- Offering a new supply, e.g., new roads financed by toll revenues, is a variation on peak pricing ("New road") (Question 2).

The methods of compensation in the case of urban tolls are the following:

- Low income compensation consists of lower toll rates for those with the lowest incomes ("Low income rate") (Question 3).

- Compensation for residents consists of lower toll rates for people residing within the toll zone ("Resident rate") (Question 3).

- Compensation for professionals consists of lower toll rates for users who need to travel for their professional activities, for example, artisans ("Business rate”) (Question 3).

- Exemptions from tolls were granted for people with low mobility ("Handicap"), drivers of carpools (“Carpool”), and emergency vehicles (“Emergency”) (Question 3).

\subsection{The econometric model}

The responses to the survey can be viewed as ordinal since they are assigned the values 1 (very unfair), 2 (unfair), 3 (fair), and 4 (very fair). Thus, the statistical model used here is an ordered probit model (McCullagh, 1980).

If $Y$ is the response factor with $K$ levels, the model can be written as follows:

$P(Y \leq k \mid x)=\Phi\left(\theta_{j}-\beta^{\prime} x\right)$,

where $\Phi$ is the cumulative normal function,

$\theta_{0}=-\infty<\theta_{1}<\cdots<\theta_{K}=\infty$ are the thresholds,

$x$ is the vector of explanatory variables, and $\beta$ is the vector of unknown parameters to be estimated. 
As each individual responds to a series of questions related to his perceptions of justice (one for each regulation or compensation rule), a fixed effect model can be developed. However, because of the problems presented by the incidental parameter, this fixed effect model cannot be estimated. The use of a conditional probit model could solve this problem, but again, the individual variables would disappear in the specification. The introduction of a random effect circumvents this problem (Butler and Moffitt, 1982). For this reason, we shall estimate an ordered probit model with random panel effects, using the "pglm" package (Panel Generalized Linear Model) of the software R (2010).

In total, 401 individuals were questioned: each individual gave an opinion of each of the six methods of regulation and the six methods of compensation, so for each of the two categories, up to 2,406 observations could be collected, including the missing values. As we use a face-toface questionnaire, the number of missing values is weak (it varies between 1 for " 3 days", "Business rate", "Handicap", "Emergency" to 5 for "Carpool").

The characteristics of the sample are presented in Table 1.

Table 1 : The socio-demographic characteristics of the sample

\begin{tabular}{|c|c|c|}
\hline Socio-demographic characteristic & Definition & Percentage $(\%)$ \\
\hline \multirow[t]{2}{*}{ Sex } & $1=$ male & 47 \\
\hline & $2=$ female & 53 \\
\hline \multirow[t]{5}{*}{ Age } & $1=$ less than 30 years & 28.5 \\
\hline & $2=$ between 30 and 39 years & 19.5 \\
\hline & $3=$ between 40 and 49 years & 18.5 \\
\hline & $4=$ between 50 and 59 years & 13 \\
\hline & $5=60$ years and over & 20 \\
\hline \multirow[t]{2}{*}{ Holding a driver's license } & $1=$ yes & 84 \\
\hline & $2=$ no & 16 \\
\hline \multirow[t]{5}{*}{ Education } & $1=$ no diploma & 8.5 \\
\hline & $2=$ lower certificate & 29 \\
\hline & $3=\mathrm{A}$ level & 24 \\
\hline & $4=$ bachelor & 18 \\
\hline & $5=$ postgraduate diploma and over & 16 \\
\hline \multirow[t]{7}{*}{ Socio-professional category } & $2=$ small businesses and retailers & 6.5 \\
\hline & $3=$ managerial and other top level professionals & 12 \\
\hline & $4=$ intermediate-level professionals & 9 \\
\hline & 5=lower-level employees & 28 \\
\hline & $6=$ blue-collars & 6 \\
\hline & $7=$ retirees & 19 \\
\hline & $8=$ students and housewives & 19 \\
\hline \multirow[t]{2}{*}{ Residential location } & $1=$ inside the toll zone & 52 \\
\hline & $2=$ outside the toll zone & 48 \\
\hline \multirow[t]{3}{*}{ Mode of transportation } & $\begin{array}{l}1=\text { exclusive user of public transportation (bus, } \\
\text { train, metro, tramway) }\end{array}$ & 20 \\
\hline & $2=$ exclusive car user & 36 \\
\hline & $\begin{array}{l}3=\text { other (walking, car }+ \text { public transport, bicycle, } \\
\text { car+train, motorcycle, bicycle+public transport, } \\
\text { bus }+ \text { public transport }+ \text { car, car }+ \text { motorcycle })\end{array}$ & 44 \\
\hline \multirow[t]{3}{*}{ Location of employment } & $1=$ employment inside the toll zone & 35 \\
\hline & $2=$ employment outside the toll zone & 34 \\
\hline & $3=$ not applicable & 31 \\
\hline
\end{tabular}

As the income question has a high level of non-responses (see Riphahn and Serfling, 2005), we only have indirect information on this point based on the level of education and profession. 


\section{Results and discussion}

Even if, in reality, the questions of regulation and compensation have a mutual influence, we want to study them separately. From the perspective of the analysis, the questions of regulation and compensation do not relate to the same concerns. Without a separate treatment, an important risk was to underestimate or miss this difference. Regulation is motivated by an objective of economic efficiency, compensation by one of justice. This difference in objectives justifies their separate treatment. It's not a hypothesis but a way to present results.

For both the regulation and compensation situations, we first present a global analysis of the perception of the underlying methods, and we then analyse the influence of individual sociodemographic variables on the perceptions of these methods.

\subsection{Perception of the methods of regulation}

a) Overview

Table 2 gives an overview of the perceptions of the methods of regulation.

Table 2: Perceptions of the methods of regulation

\begin{tabular}{llc}
\hline \multicolumn{1}{c}{ Regulation method } & \multicolumn{1}{c}{ Question } & $\begin{array}{c}\text { \% fair or very } \\
\text { fair }\end{array}$ \\
\hline $\begin{array}{l}\text { Peak pricing with a } \\
\text { constant level of supply } \\
\text { Administrative rule 1 }\end{array}$ & $\begin{array}{l}\text { To hold people responsible for traffic jams, drivers must be } \\
\text { charged a toll during peak hours "Peak pricing" } \\
\text { To reduce the automobile traffic, cars must be limited to driving } \\
\text { only every other day, depending on whether they have even or odd } \\
\text { license numbers "Odd/Even" }\end{array}$ & $32 \%$ \\
Peak pricing with & $\begin{array}{l}\text { If the money will be used to expand or build new roads, drivers can } \\
\text { be charged a toll "New road" }\end{array}$ & $34 \%$ \\
additional supply & $\begin{array}{l}\text { To reduce automobile traffic, cars must be limited to driving only } \\
\text { Administrative rule } 2\end{array}$ & $35 \%$ \\
three days per week, of their choosing, between Monday and & \\
Queuing & $\begin{array}{l}\text { Friday "3 days" } \\
\text { Automobile traffic must be allowed to evolve; people will naturally } \\
\text { adapt "Queuing" }\end{array}$ & $35 \%$ \\
Pollution pricing & $\begin{array}{l}\text { Drivers must be charged a toll to compensate for the pollution they } \\
\text { cause by driving "Pollution" }\end{array}$ & $37 \%$ \\
\hline
\end{tabular}

Regulation by pricing at peak hours ("Peak pricing") is considered the most unjust. We therefore use it as the reference method to which we compare the other methods.

b) The influence of socio-demographic variables on perceptions of the regulation methods

The fact that an individual works and the demands that imposes on mobility-especially car mobility - suggest that the attitudes of this category of people will be different from those of the rest of the population. We test this hypothesis to estimate separate models for working and non-working people (retirees, students and homemakers). We reject the hypothesis of 
stability; in other words, the two models (working and non-working) are different (p-value close to 0 , cf. Table 7 in the Appendix 1).

We consider the effects of socio-demographic variables on perceptions of the regulation methods by both working and non-working people. After several trials (Student test, 5\% critical probability, $t$-value $>1.96$ ), a certain number of significant socio-demographic variables are selected, which we then seek to simplify. A likelihood test, which compares a model based on the simplified socio-demographic variables with a model containing the non simplified variables, shows that one cannot reject the null hypothesis of identical models as to either working or non-working people (cf. Table 8 and Table 9 in Appendix 1).

For the working people, the variables of age, socio-professional category and mode of transport are simplified in the following way (Likelihood test): a group of people over 30 years old is compared to those under 30 years old; a group of small businesses and retailers, intermediate professionals and workers is compared to a group containing managers and lower-level employees; the exclusive automobile users are compared to the users of other modes of transportation.

Our results (cf. Table 3) show that managers and employees perceive all the proposed regulation rules more favourably, whereas the reverse is true for exclusive automobile users. These results also show that only the principle of paying for pollution is significantly more accepted than all the other regulation methods. These solutions are rejected, matched by the reference principle, i.e. -the peak pricing.

The standard deviation of random effect is highly significant (see Sigma), which justifies ex post the use of a random effects model.

Table 3: Perceptions of regulation methods by working individuals (ordered probit model with random-effects panel)

\begin{tabular}{|c|c|c|c|c|}
\hline Variable & Coef. & Std.error & t value & $P(>t)$ \\
\hline Constant & 0.08 & 0.125428 & 0.6514 & 0.514766 \\
\hline Under 30 & 0.13 & 0.107336 & 1.2172 & 0.223523 \\
\hline Managers and employees & 0.32 & 0.100124 & 3.2065 & $0.001344 * *$ \\
\hline Exclusive automobile users & -0.26 & 0.096185 & -2.6756 & $0.007460 * *$ \\
\hline 3days & 0.15 & 0.104460 & 1.4703 & 0.141493 \\
\hline Odd/even & 0.06 & 0.105425 & 0.5815 & 0.560891 \\
\hline New road & 0.05 & 0.104495 & 0.4540 & 0.649854 \\
\hline Pollution & 0.22 & 0.104406 & 2.1010 & $0.035644 *$ \\
\hline Queuing & 0.17 & 0.104260 & 1.6449 & 0.099989 \\
\hline \multicolumn{5}{|c|}{ Threshold parameters for index model } \\
\hline $\mathrm{Mu}(01)$ & 0.89 & 0.039795 & 22.4147 & $<2.2 \mathrm{e}-16 * * *$ \\
\hline $\mathrm{Mu}(02)$ & 2.01 & 0.065400 & 30.7112 & $<2.2 \mathrm{e}-16 * * *$ \\
\hline \multicolumn{5}{|l|}{ Std. Deviation of random effect } \\
\hline Sigma & 0.78 & 0.071886 & 10.7853 & $<2.2 \mathrm{e}-16^{* * *}$ \\
\hline Log Likelihood function & -1676.525 & & & \\
\hline Hessian & 98.1934 & & & \\
\hline Signif. codes: 0 ' $* * * *^{\prime} 0.001$ & $\because 0.1$ ‘ 1 & & & \\
\hline
\end{tabular}

For non-working people, the simplification of socio-demographic variables distinguishes those who have drivers' licenses from those who do not, and those who have diplomas from those who do not.

The results show (cf. Table 4) that for non-working people, those who have diplomas perceive all the proposed regulations as more unfair. Conversely, non-working people who do not have 
drivers' licenses perceive the proposed regulations as more fair. In addition, for non-working people, tolls for constructing new roads or for fighting pollution are judged as significantly fairer than simple peak pricing.

In this instance, the standard deviation of random effect is again highly significant (see Sigma), which justifies ex post the use of the random effects model.

Table 4: Perception of the regulation methods by non-working individuals (ordered probit model with random-effects panel)

\begin{tabular}{|c|c|c|c|c|}
\hline Variable & Coef. & Std.error & $\mathrm{t}$ value & $P(>t)$ \\
\hline Constant & 0.33 & 0.105063 & 3.1496 & $0.001635 * *$ \\
\hline No driver's license & 0.53 & 0.101552 & 5.1725 & $2.310 \mathrm{e}-07 * * *$ \\
\hline Diploma & -0.61 & 0.135730 & -4.4728 & $7.720 \mathrm{e}-06 * * *$ \\
\hline 3days & 0.19 & 0.131619 & 1.4390 & 0.150149 \\
\hline Odd/even & -0.06 & 0.132782 & -0.4296 & 0.667484 \\
\hline New road & 0.35 & 0.131491 & 2.6877 & $0.007194 * *$ \\
\hline Pollution & 0.37 & 0.132046 & 2.8368 & $0.004557 * *$ \\
\hline Queuing & 0.19 & 0.132451 & 1.4429 & 0.149035 \\
\hline \multicolumn{5}{|l|}{$\begin{array}{l}\text { Threshold parameters for } \\
\text { index model }\end{array}$} \\
\hline $\operatorname{Mu}(01)$ & 0.98 & 0.052220 & 18.7045 & $<2.2 \mathrm{e}-16 * * *$ \\
\hline $\operatorname{Mu}(02)$ & 2.35 & 0.091766 & 25.6020 & $<2.2 \mathrm{e}-16 * * *$ \\
\hline \multicolumn{5}{|l|}{$\begin{array}{l}\text { Std. Deviation of random } \\
\text { effect }\end{array}$} \\
\hline Sigma & 0.53 & 0.088830 & 5.9265 & $3.095 \mathrm{e}-09 * * *$ \\
\hline Log Likelihood function & - 1027.385 & & & \\
\hline Hessian & 86.42834 & & & \\
\hline \multicolumn{5}{|c|}{ 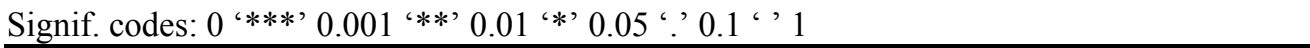 } \\
\hline
\end{tabular}

\subsection{Perception of the methods of compensation}

\section{a) Overview}

Table 5 gives an overview of the perceived justice of each of the compensation methods examined in the case of urban tolls.

Table 5: Perceptions of compensation methods

\begin{tabular}{llc}
\hline $\begin{array}{c}\text { Compensation } \\
\text { method }\end{array}$ & \multicolumn{1}{c}{ Question } & $\begin{array}{c}\text { \% fair or very } \\
\text { fair }\end{array}$ \\
\hline Resident & $\begin{array}{l}\text { People who live inside the zone have the right to a reduced rate, 1 } \\
€ \text { per day instead of 3, for a single car per household ("Resident } \\
\text { rate") }\end{array}$ & $71 \%$ \\
Professional & $\begin{array}{l}\text { Professionals (artisans, delivery services ,taxis) who need to move } \\
\text { often have the right to a reduced rate ("Business rate") }\end{array}$ & $71 \%$ \\
Low income & $\begin{array}{l}\text { People who have lower incomes have the right to a reduced rate } \\
\text { ("Low income rate") }\end{array}$ & $75 \%$ \\
Exemption 1 & Handicapped drivers are not required to pay the toll ("Handicap") & $79 \%$ \\
\hline
\end{tabular}




\begin{tabular}{llc}
\hline Exemption 2 & $\begin{array}{l}\text { Cars containing at least 3 people are not required to pay the toll, to } \\
\text { encourage people to carpool ("Carpool") }\end{array}$ & $80 \%$ \\
Exemption 3 & $\begin{array}{l}\text { Emergency vehicles (fire trucks, ambulances, police) are not } \\
\text { required to pay the toll ("Emergency") }\end{array}$ & $97 \%$ \\
\hline
\end{tabular}

The least accepted method of compensation is a reduced rate for those who live in the toll zone ("Resident rate"). We therefore use this method as the reference method.

b) The influence of socio-demographic variables on perception of compensation

Again, we first verify the hypothesis that employment is a discriminating variable in the perception of compensation methods. The likelihood test (critical probability of 0.34 , Table 10 in Appendix 1) allows us to reject the separation of the models for working and nonworking people.

We again seek to simplify the socio-demographic variables (critical probability of 0.08 , cf. Table 11 in Appendix 1). This simplification of the socio-demographic variables distinguishes a group of people under 50 from those older than 50, the exclusive users of cars from the others, and toll zone residents from non-residents.

Our results (cf. Table 6) show that the compensation methods are perceived as more unjust by those under 50 years old and by those who live outside the toll zone. In contrast, exclusive users of cars have no fixed position, in one direction or another, on these compensation methods.

The results confirm that the measures that would exempt emergency vehicles or people with limited mobility are significantly more widely accepted than the others. At the same time, the exemption for carpools and the reduced rate for low incomes also receive significantly higher acceptance, in contrast to the reduced rate for professional users, which is not significantly different from the reference method of the reduced rate for residents of the toll zone.

The use of the random effect model is once again justified by the highly significant nature of the standard deviation of random effect (see Sigma). 
Table 6: Perceptions of compensation methods (ordered probit model with randomeffects panel) ${ }^{1}$

\begin{tabular}{|c|c|c|c|c|}
\hline Variable & Coef. & Std.error & t value & $P(>t)$ \\
\hline Constant & 1.51 & 0.095393 & 15.8409 & $<2.2 \mathrm{e}-16 * * *$ \\
\hline Age under 50 & -0.22 & 0.075565 & -2.9062 & $0.003658 * *$ \\
\hline Exclusive automobile user & -0.13 & 0.074191 & -1.7539 & 0.079453 \\
\hline Residence outside toll zone & -0.17 & 0.071516 & -2.3547 & $0.018535 *$ \\
\hline Carpool & 0.22 & 0.080533 & 2.7083 & $0.006764 * *$ \\
\hline Emergency & 1.87 & 0.103252 & 18.0872 & $<2.2 \mathrm{e}-16 * * *$ \\
\hline Handicap & 0.79 & 0.084372 & 9.3349 & $<2.2 \mathrm{e}-16 * * *$ \\
\hline Low income rate & 0.19 & 0.080820 & 2.3124 & $0.020754 *$ \\
\hline Business rate & 0.16 & 0.080534 & 1.9505 & 0.051116 \\
\hline \multicolumn{5}{|c|}{ Threshold parameters for index model } \\
\hline $\mathrm{Mu}(01)$ & 0.72 & 0.039582 & 18.2261 & $<2.2 \mathrm{e}-16 * * *$ \\
\hline $\mathrm{Mu}(02)$ & 1.94 & 0.052739 & 36.8556 & $<2.2 \mathrm{e}-16 * * *$ \\
\hline \multicolumn{5}{|c|}{ Std. Deviation of random effect } \\
\hline Sigma & 0.71 & 0.057203 & 12.3624 & $<2.2 \mathrm{e}-16 * * *$ \\
\hline Log Likelihood function & - 2401.476 & & & \\
\hline Hessian & 51.97 & & & \\
\hline Signif. codes: 0 ‘***’ 0.001 & $05^{\prime}, 0.1 ،$, & & & \\
\hline
\end{tabular}

\subsection{Discussion}

The opposition to peak pricing with a constant level of supply and to pure rationing (even/odd plates) is fairly strong. At the same time, regulation by queuing seems to be equally rejected, a result which conflicts with results from the literature in other contexts (cf. table 3). For example, Frey and Pommerehne (1993) show that the traditional procedure of "first come, first served" is preferred, by far, over pricing. Raux et al. (2009) reach a similar result in the context of scarce parking spaces or seats on a train.

Result 1: Regulation by peak pricing with a constant level of supply and by rationing are widely perceived as unjust. At the same time, regulation by queuing appears to suffer the same rejection.

Whether for working or non-working people, the principle of making cars pay for the pollution they cause by driving is perceived as significantly different and less unjust than the other methods (cf. tables 3 and 4).

Result 2: A toll justified by the pollution caused by automobile traffic is less strongly rejected than the other forms of regulation.

As regards the aversion to pricing, Frey and Pommerehne claim that a price increase is less likely to be rejected when one expects the level of supply to increase. Likewise, Raux et al. (2009) show that negative attitudes towards peak pricing with a constant level of supply can be significantly moderated by the manner in which the revenues are allocated.

According to our results, this the case for non-working people who are more likely to perceive a toll for new road construction to be fairer than the peak pricing (cf. table 4).

Result 3: For the least constrained users (non-working people), the negative attitudes towards pricing can be moderated by an increase in the road supply.

\footnotetext{
${ }^{1}$ The strongly significant constant coefficient is not a sign of a wrong specification of the model but is linked to the answer structure between very unfair, unfair, fair, very fair.
} 
We proceed by detailing the analysis of the socio-demographic variables. Our results show that the differences in perception between working and non-working people exist when they are evaluating regulation methods but not when they are evaluating compensation methods (cf. tables 3 and 4).

As regards the regulation methods, our results show that the socio-professional category and the mode of transport are the significant variables for working people. Unsurprisingly, being an exclusive automobile driver and at work leads a person to perceive all regulation methods as more unfair. Nevertheless, it appears that employees and managers are less inclined to reject peak pricing (cf. table 3 ). We can suggest the idea that given the choice between dealing with congestion and pollution or paying a toll, employees and managers are not totally opposed to a toll.

On the side of the non-working people, although they seem a priori to be less constrained than the others, the opposition to a toll remains strong, especially among diploma holders (cf. table 4). However, non-working people who do not have a driver's license perceive all the proposed regulation methods as less unfair.

Result 4: Socio-professional status, educational level, and use or non-use of a car clearly play a role in individuals' perceptions of the regulation methods.

As regards perceptions of compensation methods, our results show that there are clear differences in perceptions among the methods. The "ethical" or "moral" compensation, which consists of exempting emergency vehicles from the toll, is the compensation method considered the most fair, significantly beyond all other forms of compensation. In second place is another "moral rule," namely, the exemption for handicapped people (cf. table 6). These two moral rules seem to play the role of a reference transaction as described by Kahneman et al. (1986).

Next in the order of acceptance of compensation methods is the exemption for carpools, followed by the reduced rates for people with the lowest incomes. Finally, in last place, but still considered very fair, are the reduced rates for residents of the toll zone or for certain categories of working people.

Result 5: The exemption from the toll for emergency vehicles and vehicles used by handicapped people clearly play the role of moral or ethical compensation methods. The exemption for carpools and the reduced rates for low-income individuals are the next most accepted methods of compensation.

Overall, these compensation methods are considered less fair by those who live outside the toll zone or who are under 50 years old (cf. table 6).

Result 6: People's perceptions of the justice of the compensation methods are clearly influenced by their socio-demographic situation, particularly by their ages and whether they live inside or outside the toll zone.

\section{Conclusion}

Different methods of regulation and of compensation to limit automobile traffic, derived from the empirical and theoretical literature on justice, were examined in the specific context of Lyon, France. The results may appear deceptive to the promoters of urban toll systems. The restriction of automobile traffic by prices (road tolls) or by quantities (even/odd plates or limitation of the number of days of driving) is widely considered unfair by those surveyed, whether they are working or non-working people, drivers or non-drivers. 
Meanwhile, regulation by congestion (queuing) seems to attract the same opposition, although it is the method that is most commonly used today. Moreover, the less negative attitude towards a toll based on pollution indicates a possible path for the introduction of a toll regulated according to the level of emissions of vehicles, in the model of the Ecopass Scheme in Milan (Rotaris et al., 2010).

Individuals' socio-demographic situations have clear influences on their attitudes towards the regulation methods. Among non-working people, in contrast to working people, tolls to finance new roads attract less opposition. Moreover, socio-professional status, educational level and use or non-use of an automobile play clear roles in individual perceptions of the regulation methods.

As regards compensation, there is a clear hierarchy in the perceived justice of the compensation methods. There is no doubt that emergency vehicles and those transporting people with reduced mobility should benefit from an exemption from the toll. Carpooling then appears in second place, as also deserving an exemption; this again indicates a factor in the acceptability of a toll system. However, there is a lack of explanatory variables that we need to focus on in a future research. For example, more information about the respondent constraints could be useful. Moreover, the favourable reactions to the reduced rates for low incomes indicate a concern for justice, which will be necessary to address in one form or another, although this type of compensation may be difficult to implement in the framework of an urban toll.

In addition, the socio-demographic situations of individuals, in particular, whether they live inside or outside the toll zone, also have clear influences on their attitudes towards the compensation methods. This aspect should be explored in greater detail, in particular as regards the geographic redistribution of the advantages (or inconveniences) of a toll.

These results must be understood as specific to the area in which they were taken, Lyon, and that area's or country's social, cultural, and political contexts. It is necessary to compare these results with those obtained in other urban contexts.

\section{Acknowledgements}

The research on which this article is based was supported by the ADEME (French Agency for the Environment and the Control of Energy), Grant $n^{\circ} 0003$ 040).

We would like to thank the two reviewers of Transportation Research Part $A$ for their constructive comments.

\section{References}

Armelius, H. and Hultkrantz, L. (2006) The politico-economic link between public transport and road pricing : an ex-ante study of the Stockholm road-pricing trial, Transport Policy, 13, $162-172$.

Baron, J. and Jurney, J. (1993) Norms against voting for coerced reform, Journal of Economic Personality and Social Psychology, 64, 347-355.

Bolton, L.E., Warlop, L., Alba, J.W. (2003) Consumer perceptions of (un)fairness, Journal of Consumer Research, 29, 476-491. 
Bureau, B. and Glachant, M. (2008) Distributional effects of road pricing: assessment of nine scenarios for Paris, Transportation Research Part A, 42(7), 994-1007, august.

Butler, J. S. and Moffitt, R. (1982) A Computationally Efficient Quadrature Procedure for the One-Factor Multinomial Probit Model. Econometrica, 50(3), 761-764.

Cohen, Y. (1987) Commuter welfare under peak period congestion tolls: who gains and who loses ?, International Journal of Transport Economies, XIV(3), 239-266.

Eliasson, J. (2009) A cost-benefit analysis of the Stockholm congestion charging system, Transportation Research Part A, 43(4), 468-480, may.

Eliasson, J. (2008) Lessons from the Stockholm congestion trial, Transport Policy, 15(6), 395-404.

Eliasson, J. and Mattsson, L-G. (2006) Equity effects of congestion pricing. Quantitative methodology and a case study for Stockholm, Transportation Research Part A, 602-620.

Eriksson, L., Garvill, J., Nordlund, A. (2006) Acceptability of travel demand management measures : the importance of problem awareness, personal norm, freedom, and fairness, Journal of Environmental Psychology, 26, 15-26.

Frey, B.S. and Oberholzer-Gee, F. (1996) Fair Siting Procedures: An Empirical Analysis of Their Importance and Characteristics, Journal of Policy Analysis and Management, 15(3), 353-376.

Frey, B.S., Oberholzer-Gee, F., Eichenberger, R. (1996) The old lady visits your backyard: a tale of morals and markets, Journal of Political Economy, 104(6), 1297-1313.

Frey, B.S. and Pommerehne, W.W. (1993) On the fairness of pricing - an empirical survey among the general population, Journal of Economic Behavior and Organisation, 20, 295-307.

Giuliano, G. (1992) An assessment of the political acceptability of congestion pricing, Transportation, 19(4), 335-358.

Gomez-Ibanez, J.A. and Meyer, J.R. (1993) Going private, The Brookings Institution Washington D.C., 310p.

Hicks, J. (1939) The Foundations of Welfare Economics, Economic Journal, 49, 696-712.

Hurd, M.M., McFadden, D., Chand, H., Gan, L., Menill, A., Roberts, M. (1998) Consumption and savings balances of the elderly experimental evidence on survey response bias, in Frontiers in the economics of ageing, University of Chicago Press, 353-392.

Jansson, J.O. (2008) Public transport policy for central-city travel in the light of recent experiences of congestion charging. Research in Transport Economics, 22, 179-187.

Kahneman, D., Knestsch, J.L., Thaler, R. (1986) Fairness as a constraint on profit seeking: entitlements in the market, American Economic Review, 76(4), 728-741.

Kaldor, N. (1939) Welfare propositions in economics and interpersonal comparisons of Utility, Economic Journal, 49, 549-552.

Karlstrom, A. and Franklin, J.P. (2009) Behavioural adjustments and equity effects of congestion pricing: analysis of morning commuters during the Stockholm trial, Transportation Research Part A, 43(3), 283-296.

Konow, J. (2003) Which is the fairest one of all ? A positive analysis of justice theories, Journal of Economic Literature, 41(4), 1188-1239. 
Leape, J. (2006) The London congestion charge. Journal of Economic Perspectives, 20(4), 157-176.

Mackie, P. (2005) The London congestion charge: a tentative economic appraisal. A comment on the paper by Prud'Homme and Bocarejo, Transport Policy, 12, 288-290.

Marccucci, E. (2001) Road pricing: old beliefs, present awareness and future research patterns, International Journal of Transport Economics, XXVIII, 49-80.

McCullagh, P. (1980) Regression Models for Ordinal Data. Journal of the Royal Statistical Society. Series B (Methodological), 42(2), 109-142. (with discussion).

Niskanen, W.A. (1971) Bureaucracy and representative government. Chicago :

Aldine/Atherton.

Pigou, A.C. (1920) The Economics of Welfare, MacMillan, Londres.

Prud'Homme, R. and Bocarejo, J-P. (2005) The London congestion charge : a tentative economic appraisal, Transport Policy, 1-9.

R (2010) R: A Language and Environment for Statistical Computing, R Development Core Team, R Foundation for Statistical Computing, Vienna, Austria, 2010. http://www.Rproject.org

Ramjerdi, F. (2006) Equity measures and their performance in transportation, Journal of Transportation Record Board, 1983, 67-74.

Raux, C. and Souche, S. (2004) The acceptability of urban road pricing: a theoretical analysis applied to experience in Lyon, Journal of Transport Economics and Policy, 38(2), 191-216.

Raux, C., Souche, S., Croissant, Y. (2009) How fair is pricing perceived to be? An empirical study, Public Choice, Springer, 139, 227-240.

Rawls, J. (1971) A Theory of Justice. Harvard University Press, 607p.

Richardson, H.W. (1974) A note on the distribution effects of road pricing, Journal of Economics and Policy, 8(7).

Riphahn, R. and Serfling, O. (2005) Item non-response on income and wealth questions, Empirical Economics, 30, 521-538.

Rotaris, L., Danielis, R., Marcucci, E., Massiani, J. (2010) The urban road pricing scheme to curb pollution in Milan, Italy: Description, impacts and preliminary cost-benefit analysis assessment. Transportation Research Part A, 44 (5), June, 359-375.

Ryley, T. and Gjersoe, N. (2006) Newspaper response to the Edinburgh congestion charging proposals, Transport Policy, 13(1), 66-73.

Sah, R.K. (1987) Queues, rations, and market: comparisons of outcomes for poor and the rich, The Amercian Economic Review, 77(1), 69-77.

Santos, G. (2004) Urban road pricing in the U.K., Research in Transportation Economics, 9(04), 251-282.

Santos, G. and Bhrakar, J. (2006) The impact of the London congestion charging scheme on the generalised cost of car commuters to the city of London from a value of travel time savings perspective, Transport Policy, 13, 22-33.

Santos, G. and Fraser, G. (2006) Road Pricing: Lessons from London. Economic Policy. 21(46): 264-310. 
Schade, J. and Schlag, B. (2003) Acceptability of urban transport pricing strategies, Elsevier, $329 \mathrm{p}$.

Schaller, B. (2010) New York City's congestion pricing experience and implications for road pricing acceptance in the United States, Transport Policy, 17(4), 266-273.

Small, K.A. (1983) The incidence of congestion tolls on urban highways, Journal of Urban Economics, 13, 90-111.

Taylor, G.A., Tsui, K.K.K., Zhu, L. (2003) Lottery or waiting-line auctions?, Journal of Publics Economics, 1313-1334.

Vaidyanathan, R.and Aggarwal, P. (2003) Who is the fairest of them all? An attributional approach to price fairness perceptions, Journal of Business Research, 56, 453-463.

Vickrey, W. (1963) Pricing in urban and suburban transport, American Economic Review: Papers and Proceedings, 53(2), 452-465.

Walters, A.A. (1961) The theory and measurement of private and social cost of highway congestion, Econometrica, 29(4), 676-699.

Young, H.P. (1995) Equity. In theory and practice, Princeton University Press, New Jersey, $238 \mathrm{p}$.

Zajac, E.E. (1995) Political economy of fairness, The MIT Press, Cambridge, Mass., 325p. 


\section{Appendix : Tests of likelihood, "working people" and "non-working people" models}

The likelihood test indicates if the stability hypothesis is rejected or not. It's a test for nested models. Scale issue is solved by the way that the error term follows a normal distribution (unitary variance).

Table 7: Likelihood ratio test for the regulation methods

\begin{tabular}{|c|c|c|c|}
\hline & $\begin{array}{c}\text { Regulation } \\
\text { Model I "working" + "non- } \\
\text { working" }\end{array}$ & $\begin{array}{c}\text { Regulation } \\
\text { Model II "working" }\end{array}$ & $\begin{array}{l}\text { Regulation } \\
\text { Model III “non- } \\
\text { working" }\end{array}$ \\
\hline Number of variables & $\begin{array}{c}30 \\
5 \text { for regulation, } 1 \text { for driving } \\
\text { license, } 1 \text { gender, } 4 \text { age, } 4 \\
\text { diploma, } 6 \text { professional status, } \\
2 \text { employment status, } 2 \\
\text { transport mode, } 1 \text { residence } \\
\text { inside/outside, } 1 \text { constant, } 1 \\
\text { individual effect, } 2 \text { thresholds }\end{array}$ & 28 & 25 \\
\hline $\mathrm{LnL}$ & -2799.072 & -1715.829 & -1047.637 \\
\hline Likelihood Ratio Test & Model I & I + Model III - Model I & \\
\hline LR & & 71.212 & \\
\hline df & & 23 & \\
\hline$p$-value & & $7.892696 \mathrm{e}-07$ & \\
\hline
\end{tabular}

Table 8: Likelihood ratio test to simplify the socio-demographic variables for the regulation methods ("working people")

\begin{tabular}{lc}
\hline & Regulation Model IV “working” \\
\hline Number of variables & 12 \\
& 5: regulation method, 1 age, 1 professional status, 1 \\
transport mode, 1 constant, 1 individual effect, 2 \\
thresholds \\
Likelihood Ratio Test & -1614.51 \\
LR & Model IV - Model II \\
df & 9.33 \\
$p$-value & 12 \\
\hline
\end{tabular}

Table 9: Likelihood ratio test to simplify the socio-demographic variables for the regulation methods ("non-working people")

\begin{tabular}{lc}
\hline & Regulation Model VII (“non-working”) \\
\hline Number of variables & 11 \\
& 5: regulation methods, 1 driving license, 1 diploma \\
LnL & 1 constant, 1 individual effect, 2 thresholds \\
Likelihood Ratio Test & -1051.399 \\
LR & Model VII - Model III \\
df & 7.524 \\
$p$-value & 14 \\
\hline
\end{tabular}


Table 10: Likelihood ratio test of working/non-working people for the compensation methods

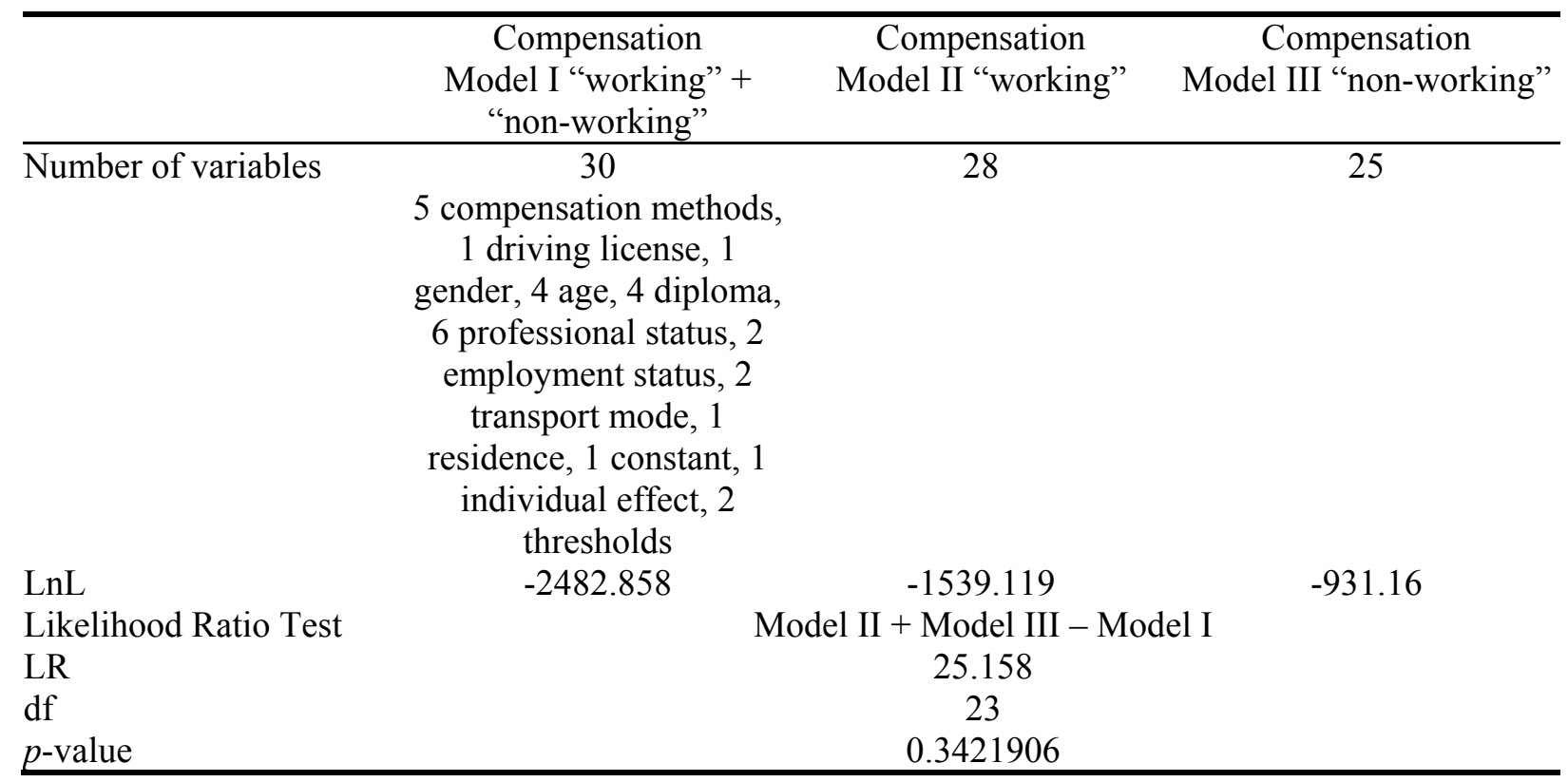

Table 11: Likelihood ratio test to simplify the socio-demographic variables for the compensation methods

\begin{tabular}{lc}
\hline Number of variables & Compensation Model IV \\
& 5 compensation methods, 1 age, 1 transport mode, 1 residence, 1 constant, \\
$\mathrm{nL}$ & 1 individual effect, 2 thresholds \\
Likelihood Ratio Test & -2496.903 \\
LR & Model IV - Model I \\
df & 26.902 \\
$p$-value & 18 \\
\hline
\end{tabular}

\section{Annex 1: The questionnaire}

The increase of automobile traffic in large cities like Lyon brings more and more serious problems, including congestion, pollution, noise and lack of safety. To stop this phenomenon, and improve the quality of life for everybody, we search now new solutions.

One of the idea studies by researchers will be to introduce a toll all around the city. That is to say drivers who travel inside the toll zone have to pay.

In Lyon, zone where toll will be applicated, would integrate central borough of Lyon and Villeurbanne. SHOW MAP and TOLL SCHEME.

Principle would be that all the car users who get through and move inside the tolled area (SHOW) would pay 3 Euro per day, Monday to Friday, between 7 a.m. to 7 p.m.

Revenues from the toll would be earmarked to the improvement of transport in Lyon, Villeurbanne and other town of the Lyon Urban Community: modernisation and extension in subway, tramway and 
buses, improvement of the security on the public transport, road maintenance, participation for financing road to avoid the city centre, improvements for walking and bicycle.

Moreover, researchers study the idea to modify bus, subways and tramway tariffs according to the hour of the trip and its distance.

Firstly, some general opinions we can have on this idea, you tell me if you find them very unfair, rather unfair, rather fair, very fair.

\section{QUESTIONS ROTATION}

\begin{tabular}{|l|l|l|l|l|}
\hline & $\begin{array}{l}\text { very } \\
\text { unfair }\end{array}$ & $\begin{array}{c}\text { rather } \\
\text { unfair }\end{array}$ & $\begin{array}{c}\text { rather } \\
\text { fair }\end{array}$ & very fair \\
\hline $\begin{array}{l}\text { Drivers must be charged a toll to compensate for the } \\
\text { pollution they cause by driving }\end{array}$ & & & & \\
\hline $\begin{array}{l}\text { To hold people responsible for traffic jams, drivers } \\
\text { must be charged a toll during peak hours }\end{array}$ & & & & \\
\hline $\begin{array}{l}\text { If the money will be used to expand or build new roads, } \\
\text { drivers can be charged a toll }\end{array}$ & & & & \\
\hline $\begin{array}{l}\text { To reduce automobile traffic, cars must be limited to } \\
\text { driving only three days per week, of their choosing, } \\
\text { between Monday and Friday }\end{array}$ & & & & \\
\hline
\end{tabular}

There would be the possibility to have different tariffs according to the type of user. I'm presenting the possibilities, and for each of them, you tell me if you find it very unfair, rather unfair, rather fair, very fair.

\begin{tabular}{|l|l|l|l|l|}
\hline & $\begin{array}{l}\text { very } \\
\text { unfair }\end{array}$ & $\begin{array}{c}\text { rather } \\
\text { unfair }\end{array}$ & $\begin{array}{c}\text { rather } \\
\text { fair }\end{array}$ & very fair \\
\hline $\begin{array}{l}\text { Emergency vehicles (fire trucks, ambulances, police) } \\
\text { are not required to pay the toll }\end{array}$ & & & & \\
\hline $\begin{array}{l}\text { Cars containing at least 3 people are not required to pay } \\
\text { the toll, to encourage people to carpool }\end{array}$ & & & & \\
\hline $\begin{array}{l}\text { People who live inside the zone have the right to a } \\
\text { reduced rate, } 1 € \text { per day instead of 3, for a single car } \\
\text { per household }\end{array}$ & & & & \\
\hline $\begin{array}{l}\text { People who have lower incomes have the right to a } \\
\text { reduced rate }\end{array}$ & & & & \\
\hline $\begin{array}{l}\text { Professionals (artisans, delivery services, taxis) who } \\
\text { need to move often have the right to a reduced rate }\end{array}$ & & & & \\
\hline Handicapped drivers are not required to pay the toll & & & & \\
\hline
\end{tabular}

And at last, if the idea of toll was applied in the city of Lyon, tell me if you will be agree or not agree with the following assertions

\begin{tabular}{|l|l|l|}
\hline & agree & not agree \\
\hline $\begin{array}{l}\text { Automobile traffic must be allowed to evolve; people } \\
\text { will naturally adapt }\end{array}$ & & \\
\hline To reduce the automobile traffic, cars must be limited to & & \\
\hline
\end{tabular}


driving only every other day, depending on whether they have even or odd license numbers 